\title{
TINJAUAN FILOSOFIS DAN TEORITIS PENGGUNAAN HUKUM ACARA HIR/RBG DALAM PENYELESAIAN SENGKETA WARIS DI PENGADILAN AGAMA
}

\author{
Domiri \\ * Hakim Pengadilan Tinggi Palembang, Sumatera Selatan \\ Korespondensi: dmrfarokha4@gmail.com \\ Naskah dikirim: 15 Maret 2016 \\ Naskah diterima untuk diterbitkan: 6 Mei 2016
}

\begin{abstract}
Act of the Republic of Indonesia, Number 7 Year 1989, Chapter 54 states that the general procedural law in Religious Courts is $H I R / R B G$. HIR/RBG is sourced from western civil law, so that in resolving all matters which are under its authority, Religious Courts conducted general procedural law of HIR/RBG sourced from western civil law, including in resolving inheritance disputes. Therefore, the procedural law of inheritance in Religious Courts which the material law sourced from islamic law would be equated with the western civil law which its material law was sourced from european law in resolving disputes. However, the material law of islamic inheritance is totally different from the material law of western civil law. Based on above discussion, there would be some research questions such as: (1) why could the Religious Court conduct the procedural law sourced from western civil law instead of procedural law sourced from islamic law in resolving the islamic inheritance disputes?, (2) How to use general procedural law of HIR/RBG in resolving inheritance disputes at the Religious Courts seen from law system? Based on the historical approach, it can be concluded that the reasons why HIR/RBG is used for resolving inheritance disputes in the Religious Courts are: first, because the Dutch colonial government policies dicriminate Islam religion. Secondly, because the Dutch colonial government policy in the field of law, they made unification and codification of law. According to the law system theory, the use of HIR/RBG in resolving inheritance disputes at the Religious Courts is less appropriate because it is not compatible with legal system components such as the substance of the law, the legal structure and legal culture.
\end{abstract}

Keywords: the religious courts, beneficiary disputes, $H I R / R B G$

\begin{abstract}
Abstrak
Undang-Undang Nomor 7 tahun 1989 Pasal 54 menentukan bahwa hukum acara yang berlaku di Pengadilan Agama adalah HIR/RBG. HIR/RBG bersumber dari hukum perdata Barat, sehingga Pengadilan Agama dalam
\end{abstract}


menyelesaikan semua perkara yang menjadi kewenangannya menggunakan hukum acara HIR/RBG yang bersumber dari hukum perdata Barat, termasuk didalamnya dalam menyelesaikan sengketa waris. Dengan demikian hukum acara waris di Pengadilan Agama yang hukum materiilnya bersumber dari hukum Islamdalam menyelesaikan sengketanya disamakan dengan hukum acara perdata Barat yang hukum materiilnya bersumber dari hukum Eropa, padahal hukum materiil waris Islam sangat berbeda dengan hukum materiil perdata Barat.Berdasarkan hal-hal tersebut maka timbul masalah sebagai berikut: (1) Mengapa hukum acara yang digunakan dalam penyelesaian sengketa waris Islam menggunakan hukum acara yang bersumber dari hukum Barat bukan hukum acara yang bersumber dari hukum Islam, (2) Bagaimana penggunaan hukum HIR/RBG dalam penyelesaian waris di Pengadilan Agama ditinjau dari sei teori sistem hukum. Berdasarkan pendekatan sejarah maka dapat disimpulkan bahwa yang menyebabkan HIR/RBG digunakan untuk penyelesaian waris di Pengadilan Agama adalah: pertama karena kebijakan politik Pemerintah Kolonial Belanda yang diskriminatif terhadap agama Islam. kedua karena kebijakan Pemerintah Kolonial Belanda di bidang hukum, yakni melakukan univikasi dan kodivikasi hukum. Penggunaan HIR/RBG dalam penyelesaian waris di Pengadilan Agama ditinjau dari segi teori sistem hukum, kurang tepat karena telah menyebabkan ketidak selarasan komponen sistem hukum yang terdiri dari substansi hukum, struktur hukum dan budaya hukum.

Kata kunci: pengadilan agama, sengketa waris, $H I R / R B G$

\section{Latar Belakang Masalah dan Permasalahan}

Indonesia adalah negara hukum, sebagaimana ketentuan yang tercantum dalam Pasal 1 ayat (3) Undang-Undang Dasar Negara Republik Indonesia Tahun 1945, yang berbunyi: Negara Indonesia adalah negara hukum. ${ }^{1}$ Menurut Padmo Wahjono terdapat berbagai rumusan negara hukum, tetapi salah satu inti dari negara hukum adalah adanya sitem tertib hukum. ${ }^{2}$ Persoalan tertib hukum tidak hanya terdapat pada teori hukum Barat tetapi terdapat pula dalam teori hukum Islam.Hal tersebut terbukti dengan adanya beberapa ayat Al-Qur'an yang membahas tentang hukum, baik hukum yang berkaitan dengan ibadah maupun yang berkaitan dengan hukum perjanjian sebagaimana dijelaskan oleh Muhammad Baqir As-Sadr sebagai berikut:

For over thousand years the great majority of Muslim jurists agreed that out of over six thousand verses in the Qur'an there were five hundred verses with legal content. Most of the "legal" verses concer ibadat, approximately acts of devotion, such as

\footnotetext{
${ }^{1}$ Lihat Undang-Undang Dasar 1945, Pasal 1 ayat (3).

2 Padmo Wahjono, "Indonesia Negara Berdasarkan Atas Hukum”, (Jakarta: Ghalia Indonesia, 1983), hal. 10.
} 
prayer and the pilgrimage. Out of these five hundred verses, there are about one hundred and ninety that deal with-non-ritual aspects of the law. Only matters of inheritance are laid out in any detail. ${ }^{3}$

Di dunia ini ada beberapa konsep negara hukum. ${ }^{4}$ Konsekwensi dari sebuah negara hukum maka maka segala persoalan yang menyangkut kehidupan warga negaranya harus diatur dalam peraturan perundang-undangan. Salah satu peraturan perundang-undangan yang mengatur warga negara di Indonesia adalah adanya Undang-Undang Nomor 7 Tahun 1989 Tentang Perdilan Agama. Salah satu aturan yang termuat dalam undang-undang tersebut adalah tentang kewenangan Pengadilan Agama yang tercantum dalam Pasal 49 yang berbunyi: yang menyatakan bahwa Pengadilan Agama bertugas dan berwenang memeriksa, memutus, dan menyelesaikan perkara-perkara di tingkat pertama antara orang-orang yang beragama Islam di bidang: (a) Perkawinan; (b) Kewarisan, wasiat, dan hibah, yang dilakukan berdasarkan hukum Islam; (c) Wakaf dan shadaqah.

Kewenangan tersebut telah bertambah sebagaimana diatur dalam Undang-Undang Nomor 3 tahun 2006. Kewenangan tambahan yang dimaksud adalah kewengan mengadili sengeta ekonomi syari'ah.

Dalam menjalankan kewenangannya Pengadilan Agama membutuhkan pranata hukum sebagai pedoman dalam menyelesaikan tugasnya. Salah satu pranata hukum yang dibutuhkan adalah hukum acara. Hukum acara ini telah diatur dalam Undang-Undang Nomor 7 Tahun 1989 Pasal 54 yang berbunyi:

Hukum Acara yang berlaku pada Pengadilan dalam lingkungan Peradilan Agama adalah hukum acara perdata yang berlaku pada Pengadilan dalam lingkungan Peradilan Umum, kecuali yang telah diatur secara khusus dalam undang-undang ini.

Berdasarkan ketentuan pasal tersebut maka hukum acara yang berlaku di Pengadilan Agama sama dengan hukum acara yang berlaku di Pengadilan Negeri yakni HIR/RBG. Hukum waris yang menjadi kewenangan Pengadilan Agama adalah bersumber dari hukum Islam. Hukum waris yang menjadi kewenangan Pengadilan Negeri adalah hukum waris yang bersumber dari hukum perdata barat. Hukum waris Islam maupun hukum waris perdata Barat masing-masing memiliki ciri sendiri-sendiri. Ciri yang membedakan antara hukum waris Islam dengan hukum waris perdata terletak pada asas-asas yang dimiliki masing-masing. Asas-asas hukum waris Islam terdiri dari:

(1) Asas Ijbari. Dalam hukum Islam peralihan harta dari orang yang meninggal kepada orang yang masih hidup berlaku dengan sendirinya.Peralihan tersebut tanpa ada usaha dari yang akan meninggal atau usaha dari yang mau menerima harta waris. Cara peralihan yang 2005), p. 2.

${ }^{3}$ Muhammad Baqir As-Sadr, "Lesson in Islamic Jurisprudence", (England: Oneworld Oxford, 
seperti ini disebut secara ijbari. Dijalankannya asas ijbari dalam hukum waris Islam mengandung arti bahwa peralihan harta dari seseorang yang telah meninggal kepada ahli warisnya berlaku dengan sendirinya menurut kehendak Allah tanpa tergantung kepada kehendak dari pewaris atau pemintaan dari ahli warisnya. ${ }^{5} \mathrm{Hal}$ ini berbeda dengan kewarisan menurut Hukum Perdata Barat yang peralihan hak kewarisan tergantung kepada kemauan pewaris serta kehendak dan kerelaan ahli waris yang akan menerima.

(2) Asas bilateral. Asas bilateral dalam kewarisan mengandung arti bahwa harta warisan beralih kepada atau melalui dua arah. Hal ini berarti bahwa setiap orang menerima hak kewarisan dari kedua belah pihak garis kerabat, yaitu pihak kerabat garis keturunan laki-laki dan pihak kerabat garis keturunan perempuan. ${ }^{6}$

(3) Asas Individual. Hukum Islam mengajarkan asas kewarisan secara individual, dengan arti bahwa harta warisan dapat dibagi-bagi untuk dimiliki secara perorangan. ${ }^{7}$ Masing-masing ahli waris menerima bagiannya secara tersendiri, tanpa terikat dengan ahli waris yang lain. Keseluruhan harta warisan dinyatakan dalam nilai tertentu yang mungkin dibagi-bagi, kemudian jumlah tersebut dibagikan kepada setiap ahli waris yang berhak untuk menerimanya.

(4) Asas keadilan berimbang. Yang dimaksudkan dengan asas ini dalam hukum waris adalah adanya keseimbangan antara hak dan kewajiban dan keseimbangan antara yang diperoleh dengan keperluan dan kegunaan. ${ }^{8}$ Atas dasar pengertian tersebut di atas terlihat asas keadilan dalam pembagian harta warisan dalam hukum Islam. Secara mendasar dapat dikatakan bahwa perbedaan gender tidak menentukan hak kewarisan dalam Islam.Artinya sebagaimana pria, wanitapun mendapat hak yang sama untuk mendapatkan warisan.

(5) Asas semata akibat kematian. Harta seseorang tidak dapat beralih kepada orang lain dengan nama waris selama yang mempunyai harta masih hidup. Dengan demikian hukum kewarisan Islam hanya mengenal satu bentuk kewarisan yaitu kewarisan akibat kematian semata. Dalam hukum perdata Barat disebut dengan kewarisan ab intestato. Dalam Islam tidak ada kewarisan atas dasar wasiat yang dibuat pada waktu masih hidup yang disebut kewarisan bij testament. ${ }^{9}$

Dari penjelasan asas-asas tersebut maka dapat disimpulkan tentang perbedaan-perbedaan hukum waris Islam dengan hukum waris perdata Barat sebagai berikut: 2013,hal 40

${ }^{5}$ Amir Syarifuddin, Hukum Kewarisan Islam, Kencana, Jakarta, 2008, hal 17

6 Suhrwardi K.Lubis dan Komis Simanjuntak, Hukum Waris Islam, Sinar Grafika, Jakarta,

${ }^{7}$ Amir Syarifuddin, Op.Cit., hal 18

${ }^{8}$ Suhrawardi K.Lubis dan Komis Simanjuntak, Op.Cit. hal 41

${ }^{9}$ Henny Tanuwidjaja, Hukum Waris Menurut BW, Refika Aditama, Bandung, 2012,hal.50 


\begin{tabular}{|l|l|l|l|}
\hline No & Bidang & Hukum waris Islam & $\begin{array}{l}\text { Hukum waris Perdata } \\
\text { Barat }\end{array}$ \\
\hline 1. & Peralihan harta & $\begin{array}{l}\text { Berlaku dengan } \\
\text { sendirinya }\end{array}$ & $\begin{array}{l}\text { Kemauan pewaris dan } \\
\text { kehendak ahli waris }\end{array}$ \\
\hline 2. & $\begin{array}{l}\text { Harta yang } \\
\text { diwariskan }\end{array}$ & $\begin{array}{l}\text { Harta yang sudah bersih } \\
\text { dari kewajiban pewaris }\end{array}$ & $\begin{array}{l}\text { Harta yang dibagi } \\
\text { termasuk hutang yang } \\
\text { dimiliki pewaris }\end{array}$ \\
\hline 3. & Sikap ahli waris & $\begin{array}{l}\text { Tidak ada hak untuk } \\
\text { menolak menjadi ahli } \\
\text { waris }\end{array}$ & $\begin{array}{l}\text { Ada hak untuk menolak } \\
\text { menjadi ahli waris }\end{array}$ \\
\hline 4. & $\begin{array}{l}\text { Sebab peralihan } \\
\text { harta }\end{array}$ & Hanya karena kematian & Bisa atas dasar wasiat \\
\hline
\end{tabular}

Dengan memperhatikan hal tersebut maka telah timbul problem filosofis yakni mengapa hukum waris yang bersumber dari hukum Islam, tetapi dalam penyelesaian sengketanya disamakan dengan hukum waris perdata Barat yakni sama-sama menggunakan hukum acara yang bersumber dari HIR/RBG.

Berdasarkan teori sistem hukum, bahwa hukum tidak akan berjalan efektif apabila tidk terdapat keselaran diantara semua komponen sistem hukum. Penyelesaian waris Islam dengan menggunakan hukum acara HIR/RBG maka secara teori telah menimbulkan persoalan tersendiri. Berdasarkan uraian tersebut maka timbul permasalahan sebagai berikut:

1. Mengapa hukum acara yang digunakan dalam penyelesian sengketa waris di Pengadilan Agama hukum acara HIR/RBG yang tidak bersumber dari hukum Islam tetapi bersumber dari hukum Barat.

2. Bagaimana penggunaan hukum acara $\mathrm{HIR} / \mathrm{RBG}$ dalam penyelesaikan sengketa waris di Pengadilan Agama ditinjau dari teori sistem hukum.

\section{Pembahasan}

\section{Kebijakan Pemerintah Kolonial Belanda}

\section{a. Kebijakan Pemerintah Kolonial Beladan Bidang Politik}

Dua dasawarsa terakhir abad ke-19 dan dua dasawarsa pertama abad ke-20 dikenal sebagai puncak abad imperialisme. Pada masa tersebut Inggris, Perancis dan lain-lainnya merajalela di Afrika dan Asia, mengancam negara-negara merdeka untuk dijadikan propinsi Eropa. ${ }^{10}$ Sedangkan Belanda di Indonesia sudah memulai politik ekspansinya jauh sebelum itu.

Pada mulanya Pemerintah kolonial Belanda tidak mencampuri urusan agama Islam tetapi setelah Snouck Hurgonje datang ke

\footnotetext{
${ }^{10}$ Aqib Suminto, Politik Islam Hindia Belanda, LP3ES, Jakarta, 1985, hal. 9.
} 
Indonesia, kebijakan Pemerintah Belanda mulai berubah. ${ }^{11}$ Pada tahun 1889 Snouck Hurgronje datang ke Indonesia.

Menghadapi kondisi Islam di Indonesia, Snouck Hurgronje membedakan Islam dalam arti ibadah dengan Islam sebagai kekuatan sosial politik. Dia membagi Islam menjadi tiga kategori, yakni: (1) Islam sebagai agama murni atau ibadah;(2) Islam dalam bidang sosial kemasyarakatan; dan (3) Islam dalam bidang politik. ${ }^{12}$

Untuk menghadapi masing-masing golongan tersebut Pemerintah Hindia Belanda memiliki kebijakan yang berbedabeda.Dalam bidang agama murni atau ibadah, pemerintah kolonial pada dasarnya memberikan kemerdekaan kepada umat Islam untuk melaksanakan ajaran agamanya, sepanjang tidak mengganggu kekuasaan pemerintah Belanda. Dalam bidang kemasyarakatan, pemerintah memanfaatkan adat kebiasaan yang berlaku dengan cara menggalakkan rakyat agar mendekati Belanda, bahkan membantu rakyat yang akan menempuh jalan tersebut. Tetapi dalam bidang ketatanegaraan, pemerintah harus mencegah setiap usaha yang akan membawa rakyat kepada fanatisme Islam.

Dalam ceramahnya di depan civitas akademica NIBA (Nederlandsch Indische Bestuars Academic) Delft pada tahun 1911, Snouck Hurgronje memberikan beberapa penjelasan mengenai politik Islamnya, yaitu: (1) Terhadap dogma dan perintah hukum yang murni agama, hendaknya pemerintah bersikap netral. (2) Masalah perkawinan dan pembagian warisan dalam Islam, perlu dihormati. (3) Tiada satu pun bentuk Pan Islam boleh diterima oleh kekuasaan Eropa.

Mengenai bidang agama murni dijelaskan bahwa pemerintah seharusnya tidak menyinggung dogma atau ibadah murni agama Islam, sebab sebagaimana dogma agama lain yang dijamin kemerdekaannya, dogma ini tidak berbahaya bagi pemerintah. Menurut Snouck Hurgronje, di kalangan umat Islam akan terjadi suatu perubahan pelan-pelan meninggalkan agamanya. Setiap campur tangan pemerintah dinilainya akan memperlambat proses evolusi tersebut.Lagi pula tindakan seperti itu sangat berlawanan dengan asas kemerdekaan beragama.

Mengenai bidang perkawinan dan waris yang dalam pandangan Barat termasuk bidang hukum, harus dihormati sebagaimana bidang agama. Mengenai bidang ketiga,Snouck Hurgronje menilai gegabah andaikata pemerintah tidak turun tangan terhadap fanatisme Islam.

Menurut Daliar Noer, orang-orang Belanda beranggapan bahwa pertukaran agama penduduk menjadi Kristen akan menguntungkan negeri Belanda karena dengan masuk Kristen maka mereka hubungannya menjadi erat dengan pemerintah yang sama-sama

\footnotetext{
${ }^{11}$ Ibid., hal. 10.

${ }^{12}$ Ibid., hal. 22.
} 
memeluk agama Kristen. Dengan demikian mereka akan menjadi warga negara yang loyal lahir batin kepada Pemerintah. ${ }^{13}$

Karena pengaruh pendapat Snouch Hurgronye, maka garis kebijakan Pemerintah untuk tidak ikut campur dalam bidang ibadah murni, tidak berjalan lama. Hal tersebut dapat terlihat dari beberapa kebijakan yang merugikan Islam, antara lain:

(1) VOC (Verenigde Oost Indische Companie) sebagai perkumpulan perdagangan, memang tidak memiliki politik Islam, tetapi hanya berusaha mencari keuntungan. Tugas yang harus dilaksanakan oleh VOC adalah (1) Melakukan ekploitasi ekonomi demi mengatasi krisis ekonomi di negeri Belanda, (2) Mendisiplinkan rakyat pribumi dengan cara otoriter, (3) melindungi pegawai VOC dengan sanak kerabatnya dan melindungi pendatang Eropa. ${ }^{14}$ Sementara itu, diluar tugas tersebut VOC ditugaskan untuk menyebarkan agama Kristen. Cara yang ditempuh oleh VOC adalah dengan mengeluarkan larangan orang Islam untuk melaksanakan ibadah haji ke Makkah.

(2) Pemerintah Hindia Belanda yang tidak aktif memperhatikan kepentingan Zending, akan mendapat teguran keras dari Partai Kristen yang berada di Parlemen.

(3) Pidato tahunan raja pada bulan September 1901 menyatakan mempunyai kewajiban etis dan tanggung jawab moral kepada rakyat Hindia Belanda, yakni memberikan bantuan lebih banyak kepada penyebaran agama Kristen.

Akibat kebijaksanaan tersebut, timbulah kritik tajam di kalangan umat Islam, bahwa pemerintah kolonial melancarkan kersteningspolitiek, yaitu kebijaksanaan yang menunjang kristenisasi. Kritik ini antara lain didasarkan pada kenyataan adanya surat edaran Idenburg tersebut dan pembangunan rumah sakit zending di Solo dengan subsidi Pemerintah.

b.Kebijakan Pemerintah Kolonial Belanda bidang hukum

Disamping kebijakan politik, ada juga kebijakan hukum atau legal policy. ${ }^{15}$.Adapun uraian politik hukum Islam Belanda adalah sebagai berikut.

Menurut Bustanul Arifin, ${ }^{16}$ ada tiga cara yang ditempuh oleh Pemerintah Belanda dalam upaya melemahkan hukum Islam di

\footnotetext{
${ }^{13}$ Deliar Noer, Gerakan Modern Islam di Indonesia, 1900-1942, LP3ES, 1980, hal.2

${ }^{14}$ Moh. Fauzan Januri, Pengantar Hukum Islam Pranata Sosial, Pustaka Setia Bandung,2013, hal.62

${ }^{15}$ Lega politik adalah kebijakan resmi tentang hukum yang akan diberlakukan baik dengan pembuatan hukum baru maupun dengan penggantian hukum lama, dalam rangka mencapai tujuan negara. Moh.Mahfud MD, Politik Hukum di Indonesia, Rajawali Pers, Jakarta, 2011, hal 1

${ }^{16}$ Jazuni, Legislasi Hukum Islam Di Indonesia, Citra Aditya Bakti Bandung, 2005, hal. 237
} 
Indonesia, yakni: (1) Univikasi hukum; (2) menghidupkan hukum adat; (3) membangun citra jelek terhadap Pengadilan Agama. Uraian ketiga hal tersebut adalah sebagai berikut:

\section{1) Unifikasi Hukum}

Menurut penulis sejarah Australia, John Ball yang dikutip oleh Soetandyo Wignjosoebroto, perkembangan sistem hukum dan tata hukum di Indonesia dibagi menjadi tiga periode,yakni: pertama periode tahun 1840-1890; kedua, periode 1890-1940; ketiga periode tahun 1940-1990. ${ }^{17}$ Pada periode 1890 sampai dengan tahun 1940 adalah tahun-tahun yang dipengaruhi politik etik pemerintah. ${ }^{18}$ Pada periode ini Pemerintah kolonial berusaha untuk meningkatkan kesejahteraan ekonomi dan sosial penduduk pribumi melalui kebijakan 'voogdij' (pewalian, pengasuhan).

Dominasi politik etik yang bertujuan untuk memajukan kehidupan rakyat pribumi ternyata dalam perkembangannya tetap menimbulkan kontroversi antara kelompok universalis dengan kelompok partikularis. Kelompok universalis berkeyakinan bahwa penduduk tanah jajahan akan maju dan meningkat taraf hidupnya melalui eropanisasi kultur. Sedangkan kelompok partikularis berkeyakinan bahwa kemajuan dan peningkatan taraf hidup penduduk pribumi dapat dilaksanakan tanpa meng-Eropa-kan terlebih dahulu secara paksa dan semena-mena kehidupan penduduk itu.

Di saat dilaksanakannya politik etik oleh pemerintah kolonial, Pemerintah kolonial tetap memiliki kebijakan untuk menyegerakan majunya pengaruh peradaban Belanda ke daerah jajahannya. Dengan demikian Pemerintah tidak hanya memperluas pendidikan yang bertolak dari nilai-nilai Barat, tetapi juga mencoba untuk melakukan Eropanisasi hukum kolonial di Hindia Belanda. Dengan didasari semangat poltik etik, para pejabat tinggi tetap melaksanakan kebijakan kodifikasi dan unifikasi hukum secara konsekuen ${ }^{19}$.

Pada tahun 1904, P.J. Idenburg yang pada waktu itu menjabat jabatan Menteri Koloni mengajukan rancangan undang-undang tentang pengkodifikasian hukum perdata materiil untuk seluruh golongan penduduk di Indonesia, berdasarkan Burgerlijk Wetboek Negeri Belanda. Dalam rancangan tersebut juga terdapat perkecualian, misalnya mengenai aspek hukum tanah, hukum keluarga dan waris bagi yang beragama Islam. Rancangan undangundang Idenburg ini mengalami banyak perubahan agar kekhususankekhususan hukum yang hidup dan berlaku di kalangan orang-orang pribumi dapat tertampung. Perubahan tersebut banyak diajukan oleh

\footnotetext{
${ }^{17}$ Soetandyo Wignjosoebroto, Dari Hukum Kolonial Ke Hukum Nasional, Raja Grafindo Persada, Jakarta, 1995, hal.3

${ }^{18}$ Sotandyo Wignjosoebroto, Hukum, Paradigma, Metode dan Dinamika Masalahnya, ELSAM, Jakarta, 2002,hal.252

${ }^{19}$ Sortandyo Wignyosoebroto, op.cit., hal 257
} 
J. W. H. M. van Idsinga. Walaupun pada tahun 1906 rancangan undang-undang Idenburg ini disetujui parlemen, dan telah diumumkan oleh pemerintah, akan tetapi sampai saatnya yang terakhir ternyata hasil rencana kerja Idenburg ini tidaklah pernah diimplementasikan dan dioperasikan dalam praktek.

Agak berbeda dengan sikap para politisi yang bersimpati dengan nasib rakyat pribumi, pada masa puncak pengaruh liberalisme mendukung kebijakan partikularistik dengan cara membiarkan orang-orang pribumi menikmati hukumnya sendiri justru menyokong politik unifikasi. C. Th. van Deventer, yang pada tahun 1899 telah terkenal dengan tulisannya tentang "Men Ereschuld", telah menyokong rancangan undang-undang Idenburg, dan dalam tulisannya yang terbit pada tahun 1905 mengutip apa yang pernah diungkapkan oleh Th. B. Macaulay, "uniformity when you can have itu diversity when you must have itu, but in all cases certainty. Van Deventer pun mengakui, bahwa sekalipun kenyataan yang ada setempat memang memerlukan adanya keragaman hukum, akan tetapi sesungguhnya keragaman seperti itu tidak perlu dipertahankan.

\section{2) Kodifikasi hukum sebagai upaya memperlancar univikasi hukum}

Sebelum membahas lebih lanjut mengenai kodivikasi hukum yang dilakukan Pemerintah Belanda, terlebih dahulu penulis menjelaskan tentang pengertian kodivikasi sebagai berikut:

Menurut Satjipto Rahardjo, kodivikasi adalah usaha orang untuk mencari jalan bagaimana dapat menguasai badan perundangundangan dengan baik karena peraturan itu sudah menjadi demikian banyak. $^{20}$ Menurut Soerjono Soekanto dan Mustafa Abdullah, ${ }^{21}$ kodifikasi hukum sebenarnya berarti menyusun buku yang memuat bidang hukum tertentu, yang dilakukan secara sistimatis dan konsisten. Di dalam kodifikasi ini diusahakan, agar bidang hukum tertentu tersebut disajikan secara setuntas mungkin. Kebutuhan untuk melakukan kodivikasi timbul pada saat hukum perundangundangan sudah berkembang menjadi suatu badan yang demikian besar dan banyak sehingga orang tidak bisa dengan mudah memperoleh orientasi. Tujuan umum kodifikasi adalah untuk kempulan perundang-undangan itu sederhana dan mudah dikuasai, tersusun secara logis, serasi dan pasti. ${ }^{22}$ Menurut C.S.T Kansil, ${ }^{23}$ kodivikasi adalah pembukuan jenis-jensi hukum tertentu dalam kitan undang-undang secara sistimatis dan lengkap. Dengan demikian

\footnotetext{
${ }^{20}$ Satjipto Rahardjo, Ilmu Hukum, Citra Aditya Bakti, Bandung, 2012, hal.91.

21 Soerjono Soekanto dan Mustafa Abdullah, Sosiologi Hukum dalam Masyarakat, Jakarta: Rajawali, 1980, hal. 73-74.

${ }^{22}$ Satjipto Rahadjo, op.cit. hal 92

${ }^{23}$ C.S.T Kansil, Pengantar Ilmu Hukum Indonesia, Rineka Cipta, Jakarta, 2014, hal.78
} 
maka unsur-unsur kodifikasi terdiri dari: jenis-jenis hukum tertentu, sistematis dan lengkap. Kodifikasi (Belanda: codificatie; Inggris: codification), diartikan sebagai pengumpulan sejumlah ketentuan dan peraturan serta perundang-undangan yang disusun menjadi sebuah buku hukum atau buku perundang-undangan. ${ }^{24}$

Fockema Andreas mengartikan bahwa codificatie adalah: "Het samensellen en invoeren van systimatisch ingerichte wetboeken (codices) voor rechtsgebieden van enige omvang." (menyusun dan membawa masuk secara teratur dan sistimatik ke dalam kitab undang-undang dalam bidang hukum dengan ruang lingkup yang luas. ${ }^{25}$

Dari berbagai kutipan definisi di atas dapat disimpulkan bahwa kodifikasi adalah proses menghimpun dan menyusun secara sistimatik berbagai hukum, regulasi atau peraturan di bidang tertentu yang ditetapkan oleh negara. Produk dari kegiatan kodifikasi dapat berupa kitab undang-undang.

Kodifikasi yang disamakan dengan kitab undang-undang, cakupannnya lebih luas dibanding dengan undang-undang. Ia bisa mencakup hukum tertentu secara keseluruhan yang tidak didapatkan dalam sebuah undang-undang biasa. ${ }^{26}$

Istilah wet dan wetboek dalam bahasa Blanda yang diterjemahkan ke dalam bahasa Indonesia dengan "undang-undang" atau "kitab undang-undang", selalu pada bentuk formal yang telah ditentukan dalam peringkat perundang-undangan yang berlaku. ${ }^{27}$

Kodifikasi hukum dalam sejarah Islam sudah lama terjadi. Pada waktu Sultan Sulaiman I, seorang raja dari Dinasti Utsmaniyah berkuasa, ia menyuruh Syaikh Islam Abu Sa'ud untk menyusun kodifikasi undang-undang yang akan diberlakukan pada seluruh negara.Kodifikasi tersebut dilaksanakan dengan mengambil sumber dari fiqih madzhab Abu Hanifah dengan meteri yang disesuaikan dengan situasi dan kondisi. ${ }^{28}$ Dari usaha tersebut tersusunlah kodifikasi hukum Islam yang dikenal dengan nama Qonun Namah Sultan Sulaiman.Pada pertengahan abad ke 16 Masehi Sultan Sulaiman I juga memerintahkan Syaikh Ahmad al Jalabi, khotib masjid Sultan untuk mengumpulkan hukum-hukum fiqih dalam bentuk kodivikasi yang diringkas. Tugas tersebut dapat dilaksanakan

${ }^{24}$ Yan Pramudya Puspa, Kamus Hukum Edisi Lengkap Bahasa Belanda, Indonesia, Inggris, Semarang: Aneka Ilmu, 1977, hal. 521

${ }^{25}$ Ibid

26 Ahmad Muchsin Asyrof, "Syari'at Islam dan Hukum Positif di Indonesia" dalam Jurnal Hukum Program Studi Ilmu Hukum Pascasarjana Universitas Sriwijaya, Volume VI Nomor I Januari 2008, hal.79.

${ }^{27}$ Abdurrahman, Kompilasi Hukum Islam di Indonesia, Jakarta: Akademi Presindo, 1992, hal.9.

${ }^{28}$ Abdul Manan, Reformasi Hukum Islam di Indonesia, Raja Grafindo Persada, Jakrta, 2006, hal 
dengan baik sehingga tersusunlah sebuah kodifikasi dalam madzhab dengan judul Multaqa al-Abhar. Kodifikasi ini beserta syaratsyaratnya masih merupakan rujukan dalam mempelajari hukum Islam dalam mazhab Hanafi meskipun tidak memiliki penetapan resmi dari negara ${ }^{29}$

Pada abad ke-17 Sultan Muhamad Aurang Zeb Bahadur Alamkir alHindi memerintahkan sejumlah ulama besar mazhab Hanafi untuk menyusun kodifikasi dzahir riwayat-riwayat yang disepakati. Kodifikasi ini kemudin dijadikan sumber fatwa oleh para ulama besar dan rujukan oleh hakim dalam memutuskan suatu perkara. Disamping itu, Sultan Muhamad Aurang Zeb juga memerintahkan untuk mengumpulkan pendapat-pendapat yang belum disepakati dan masih diterima oleh para ulama. Usaha ini dilaksanakan oleh sebuah panitia yang dibentuknya.Setelah bekerja beberapa tahun panitia tersebut menyusun sebuah kodifikasi yang diberi nama al-Fatwa alAlamkiriah atau disebut juga al-Fatwa al-Hidayah yang terdiri dari enam jilid besar dan merupakan rujukan yang mashur tentang fiqih Hanafi. ${ }^{30}$

Menurut Soerjono Soekanto dan Mustafa Abdullah bahwa Kodifikasi hukum dilakukan untuk memenuhi dan mencapai tujuan tertentu, yaitu Pertama untuk mencapai kesatuan dan keseragaman hukum (rechtseenheid), kedua, untuk mencapai kepastian hukum (rechtszekerheid), dan yang ketiga, untuk penyederhanaan hukum (rechtsvereenvoudiging). ${ }^{31}$ Lebih lanjut ditegaskan bahwa didalam mengadakan kodifikasi hukum, maka ketiga dari tujuan kodifikasi seperti dikemukakan di atas tidak berdiri sendiri, karena tujuan kodifikasi tidak akan mungkin tercapai, bila hanya satu atau dua tujuan yang dalam kenyataan benar-benar terwujud.

\section{3) Dasar hukum kodifikasi Hukum Belanda di Indonesia.}

Negeri Belanda pernah dijajah Perancis yang dipimpin Napoleon. Pada waktu menjajah negeri Belanda, Perancis telah memberlakukan beberapa kitab hukum, yakni kitab hukum perdata (Code Civil), kitab hukum dagang (Code Commerce) dan hukum pidana (Code Penal). Ketika kekuasaan Napoleon runtuh dan negeri Belanda terbebas dari jajahan Perancis ketiga kitab hukum hasil kodifikasi Napoleon dinyatakan tetap berlaku sebagai kitab rujukan untuk menyelesaikan perkara-perkara hukum di pengadilan negeri Belanda. Setelah kekuasaan Napoleon runtuh, masyarakat negeri Belanda timbul semangat nasionalisme untuk membuat kodifikasi yang lebih

\footnotetext{
${ }^{29}$ Umar Sulaiman al-Asyqar,Tarikh al-Fiqh, al Islami, Terjemahan Drs.Dedi Jumaedi dan Ahmad Nurahman, Fiqih Islam Sejarah Pembentukan dan Perkembangannya, Jakarta, Akademika Pressindo, 2001, hal 228

${ }^{30}$ Abdul Manan, op.cit., hal. 190

${ }^{31}$ Soerjono Soekanto dan Mustafa Abdullah, Op.Cit., hal.74
} 
merefleksikan hukum rakyat Belanda sendiri sebagai pengganti Codes Napoleon. Penyusunan kitab undang-undang tersebut telah selesai pada tahun 1830 oleh Panitia Kemper kecuali kitab hukum pidana. Kitab Undang-Undang Hukum Perdata hasil karya Panitia Kemper diundangkan pada tanggal 5 Juli 1830 dengan sebuah surat Koninklijk Besluit dan dinyatakan mulai berlaku sejak tanggal 1 Februari 1831. Pemberlakuan kitab undang-undang tersebut bersamaan dengan rencana memberlakukan kitab-kitab yang lain yakni Kitab Undang-Undang Hukum Dagang, Kitab UndangUndang Hukum Acara Perdata dan Kitab Undang-Undang Hukum Acara Pidana.

Pada bulan Agustus 1830 terjadi suatu kejadian yang membuat situasi memanas. Wakil-wakil dari daerah selatan pada waktu itu menyatakan keberatan atas diberlakukannya kitab-kitab hasil karya Panitia Kemper. Mereka beralasan norma yang terkandung dalam kitab undang-undang tersebut banyak didominasi oleh ide hukum orang-orang Holland yang berada di wilayah utara, dan tidak memberikan apresiasi kepada asas-asas dan nilai-nilai hukum yang hidup di kalnagan masyarakat selatan. Mereka lebih setuju dengan diberlakukannya Codes Napoleon. Dengan adanya protes tersebut maka berlakunya kitab undang-undang hasil kerja Panitia Kemper terpaksa harus ditangguhkan. Prpopinsi-propinsi selatan pada akhirnya memisahkan diri dari negara Belanda dan membentuk negara baru dengan nama Belgia, dan menggunakan kitab undangundang sendiri. Kemudian pada tahun 1838 Kitab undang-undang hasil kerja Panitia Kemper baru diberlakukan kembali.

Bagaimana berlakunya kitab undang-undang di negeri jajahan. Aturan hukum negeri Belanda menegaskan bahwa berdasarkan asas konkordansi bahwa pada prinsipnya hukum yang berlaku di daerah jajahan untuk orang-orang Eropa adalah hukum yang berlaku di negara Belanda. Ketika Codes Napoleon diberlakukan di negeri Belanda, hukum yang berlaku di Hindia Belanda adalah ordonansiordonansi dan instruksi-instruksi eksekutif serta maklumat-maklumat yang diundangkan secara lepas-lepas di plakat-plakat. ${ }^{32}$ Ketika negeri Belanda lepas dari jajahan Prancis, maka penduduk yang di Belanda maupun yang ada di Hindia Belanda menginginkan memiliki kodifikasi sendiri. Keinginan tersebut harus menunggu sampai Panitia Kemper menyelesaikan hasil kerjanya.Ketika Panitia Kemper pada tahun 1830 telah menyelesaikan kitab-kitab hukum untuk negeri Belanda dan siap diundangkan, para penguasa kolonial di Hindia Belanda menanti tindakan pemerintah Belanda untuk memberlakukan kitab-kitab hukum yang telah disusun tersebut di tanah jajahan Belanda.

${ }^{32}$ C.S.T Kansil, op.cit., hal. 195 
Pada bulan Juli 1830 atau selang beberapa hari sejak turunnya keputusan raja yang mengundangkan Kitab Undang-Undang Hukum Perdata untuk negeri Belanda, raja memberikan instruksi kepada G.C. Hageman, seorang ahli hukum yang baru saja diangkat sebagai Ketua Hooggerechtshof Hindia Belanda untuk masa 1830-1835. Instruksi tersebut berisi perintah guna menyusun kitab undangundang untuk negeri Hindia Belanda. Pengangkatan G.C. Hageman sebagai Ketua Hooggrechtshof dengan intruksi Koninklijk Besluit tahun 1830 nomor 96. Berdasar pada surat tersebut maka Hageman berangkat ke negeri Hindia Belanda untuk menempati posnya yang baru dan untuk memulai kerjanya yang baru. Namun demikian sampai dengan akhir masa jabatannya Hagemen tidak menghasilkan kerja apapun. Hageman tidak melakukan apapun atas tugasnya untuk meyusun kodifikasi hukum dengan cara konkordan dengan hukum yang berlaku di Belanda. Hageman sempat ditegur oleh Gubernur Jenderal dengan suatu resolusi bertanggal 10 Agustus 1835 tentang belum berhasilnya menyusun kodifikasi hukum untuk Hindia Belanda. Hagemen menjawab bahwa yang menyebabkan belum bekerja untuk menyusun kodivikasi karena kodifikasi hukum di negeri Belanda sendiri belum dinyatakan berlaku. Tidak banyak pihak yang bersedia menerima dan membenarkan alasan Hageman ini. Menurut mereka apapun yang terjadi di negeri Belanda seharusnya Hageman tetap melaksanakan tugasnya, sekurangkurangnya Hageman mempelajari langkah-langkah apa saja yang harus dipertimbangkan dan diperkirakan untuk kepentingan tanah jajahan manakala pada suatu saat kitab-kitab kodifikasi di negeri Belanda tersebut dinyatakan mulai berlaku.

Pada tanggal 2 Februari 1836 Gubernur Jenderal menyatakan bahwa sekalipun Kitab Undang-Undang Hukum Perdata yang baru belum ditentukan kapan tanggal berlakunya, akan tetapi Hageman mestinya dapat membuat penilaian-penilaian sejauh mana asas-asas pokok yang terkandung dalam kitab itu dapat diterapkan di Hindia Belanda. Beberapa bulan kemudian, pada tanggal 8 Juni 1836 Hageman mengajukan permohonan agar ia dibebaskan dari tugasnya sebagai Presiden Hooggrechtshof Hindia Belanda, dan Raja segera saja mengabulkan permohonan itu.

Mundurnya Hageman dari percaturan sejarah kodifikasi Hindia Belanda membuka peluang yang bagus untuk masuknya seorang pemerhati yang juga relewan, yang mewakili zamannya, kemudian tercatat sebagai orang yang punya peran penting dalam proses lahirnya kitab-kitab kodifikasi Hindia Belanda. Pemerhati dan pekerja relawan ini adalah seoarng ahli hukum bernama Scholten van Oud Haarlem. Di tangan Scholten inilah kegiatan mempersiapkan kodifikasi untuk tanah jajahan menjadi aktif. Karena aktif dalam mewujudkan kodifikasi hukum tersebut, Scholten pada bulan September 1837, setahun sebelum hasil-hasil kodifikasi 
Kemper dinyatakan berlaku di negeri Belanda, Scholten sudah berhasil menuangkan gagasan-gagasannya tentang introduksi kodifikasi hukum Belanda ke tanah jajahan. Scholten kemudian diangkat sebagai Ketua Komisi Hindia Belanda untuk kerja perundang-undangan berdasarkan surat keputusan Gubernur Jenderal de Eerens tanggal 31 Oktober 1837 nomor 1. Kemudian karena prestasinya, dua tahun kemudian dia dipromosikan sebagai Ketua Komisi di Negeri Belanda untuk tugas yang sama berdasarkan Koninklijk Busluit tanggal 15 Agustus 1939 nomor 102. Bekerjanya Scholten berakhir secara resmi pada tanggal 15 Desember 1845. Pada saat itu sebagian besar tugas perundang-undangan yang diemban Scholten van Oud Haarlem telah selesai dikerjakan. Kemudian sebagai penerusnya adalah bernama H.L.Wiches, tinggal menyempurnakan dan kemudian menyiapkan langkah pengundangan saja.

Dasar hukum dari kodifikasi situ tercantum pada pasal 75 ayat 1 Regerings-Reglement (R.R.) yang kemudian diganti menjadi pasal 131 ayat 1 Indishe Staatsregling (I.S.), yaitu Peraturan Ketatanegaraan Hindia Belanda, yang berbunyi: "Hukum Perdata dan Hukum Dagang begitu pula Hukum Pidana beserta Hukum Acara Perdata dan Hukum Acara Pidana harus diletakkan dalam Undang-Undang" (yaitu harus dikodifikasikan). ${ }^{33}$ Hukum kodifikasi (misalnya Hukum Perdata, Hukum Dagang, Hukum Pidana) yang sekarang berlaku di Indonesia adalah selaras (konkordan) dengan Hukum Kodifikasi yang berlaku di negeri Belanda. Keselarasan Hukum Kodifikasi tersebut disebabkan berlakunya asas konkordansi (asas keselarasan asas persamaan berlakunya sistem hukum) di Indonesia. Asas konkordansi diatur dalam Indishe Staatsregeling yang berbunyi:

(a) Hukum perdata dan dagang, begitu pula hukum pidana beserta hukum acara perdata dan pidana harus dikodifisir yaitu diletakkan dalam kitab undang-undang.

(b) Untuk golongan bangsa Eropa untuk itu harus dianut peraturan perundangan yang berlaku di Negara Belanda.

(c) Untuk golongan bangsa Indonesia asli dan Timur Asing jika ternyata bahwa kebutuhan kemasyarakatan mereka hendaki didapatlah peraturan-peraturan untuk bangsa Eropa dinyatakan berlaku bagi mereka, baik seutuhnya maupun dengan perubahan-perubahan, dan juga diperbolehkan membuat suatu peraturan baru bersama, selain harus diindahkan aturan-aturan yang berlaku di kalangan mereka, dari aturan-aturan mana yang boleh diadakan penyimpangan jika diminta oleh kepentingan umum atau kebutuhan kemasyarakatan mereka. 
(d) Orang Indonesia asli dan Timur Asing, sepanjang mereka belum ditundukan di bawah suatu peraturan bersama dengan orang Eropa, diperbolehkan menundukan diri pada hukum yang berlaku untuk orang Eropa, penundukan yang mana boleh dilakukan baik seluruhnya maupun hanya mengenai sesuatu perbuatan tertentu

(e) Sebelum hukum untuk orang Indonesia itu ditulis di dalam undang-undang, maka bagi mereka akan tetap berlaku hukum yang sekarang berlaku bagi mereka. ${ }^{34}$ Berdasarkan ketentuan tersebut berarti hukum yang berlaku bagi orang-orang Belanda di Indonesia harus dipersamakan dengan hukum yang berlaku di negeri Belanda. Jadi selarasnya hukum kodifikasi di Indonesia dengan hukum kodifikasi di negeri Belanda adalah berdasarkan asas konkordansi tersebut. Namun demikian hukum kodifikasi yang berlaku di Belanda ini umumnya juga mencontoh hukum kodifikasi yang berlaku di Perancis, yang pada akhirnya kodifikasi Perancis berinti pangkal pada hukum kodifikasi di Romawi Kuno.

\section{Upaya Menyelaraskan Komponen Sistem Hukum}

Dalam ilmu hukum terdapat istilah sistem hukum. Untuk mengenal lebih dalam mengenai istilah sistem hukum maka kita lebih dahulu harus mengenal istilah "sistem". Istilah "sistem" berasal dari bahasa Yunani "systema" yang mengandung arti keseluruhan ( $a$ whole $)$ yang terdiri dari banyak bagian. Systema juga berarti, hubungan yang berlangsung di antara satuan-satuan atau komponen secara teratur. ${ }^{35}$ Sedangkan definisi "sistem" menurut Bartalanffy yang dikutip oleh Lili Rasjidi adalah $a$ complex of elements in mutual interaction ${ }^{36}$ Sistem diartikan sebagai suatu komplek elemen dalam suatu kesatuan interaksi. Kemudian definisi "sistem" menurut Campbell yang dikutip oleh Tatang Amirin adalah We might define a system as any group of interrelated component or parts which function together to achieve a goal. Yang artinya bahwa sistem itu merupakan himpunan komponen atau bagian yang saling berkaitan yang bersama-sama berfungsi untuk mencapai suatu tujuan.

Menurut Soerjono Soekanto ${ }^{37}$ faktor-faktor yang relevan untuk dibahas dalam masalah sistem adalah: (1) elemen-elemen suatu sistem (2) pembagian sistem, (3) konsistensi, (4) pengertian-pengertian dasar (grondbegrippena) dari sistim.

\footnotetext{
${ }^{34}$ Pasal 131 I.S

35 Tatang M.Amirin, Pokok-Pokok Teori Sistem, Rajawali Pers, Jakarta, 1996, hal. 18

36 Lili Rasjidi, I.B.Wyasa Putra, Hukum Sebagai Suatu Sistem,Mandar Maju, 2003,Bandung,hal.63

37 Soerjono Soekanto dan Purnadi Purbacaraka,Sendi-Sendi Ilmu Hukum, Citra Aditya Bakti, Bandung, 1993, hal. 39.
} 
Menurut Winardi, ${ }^{38}$ sistem ada dua macam yakni sistem terbuka dan sistem tertutup. Sistem terbuka adalah sebuah sistem yang mempunyai hubungan dengan lingkungan. Sedangkan sistem tertutup adalah sistem yang terisolasi dari lingkungan.

Setelah mengetahui istilah dan pengertian sistem, tidak kalah pentingnya kita juga harus mengetahui tentang ciri-ciri "sistem". Ciri-ciri "sistem" menurut Ismail Saleh, ${ }^{39}$ dalah sebagai berikut: (1) saling keterkaitan antara satu komponen dengan komponen lain, saling membatasi, tetapi juga saling memperkuat, (2) dinamis, tetapi tetap terjaga keserasian dan keseimbangannya, (3) terbuka, tetapi tetap tidak kehilangan eksistensinya dan identitasnya, (4) galir dalam arti tidak kaku, sehingga dapat menampung.

Menurut Solly Lubis, ${ }^{40}$ hukum merupakan suatu sistem, maka pendekatan yang dilakukan adalah pendekatan sistem dan bukan pendekatan kekuasaan. Oleh karena pembahasan masalah ini berkaitan dengan sistem hukum maka perlu dipahami juga mengenai pengertian sistem hukum.

Dalam menjelaskan tentang hukum sebagai suatu sistem, Sudikno Mertokusumo, ${ }^{41}$ mengatakan sebagai berikut:

Hukum merupakan sistem berarti bahwa hukum itu merupakan tatanan, merupakan suatu kesatuan yang utuh yang terdiri dari bagian-bagian atau unsur-unsur yang saling berkaitan erat satu sama lain. Dengan perkataan lain sistem hukum adalah suatu kesatuan yang terdiri dari unsur-unsur yang mempunyai interaksi antara satu sama lain dan bekerja sama untuk mencapai tujuan kesatuan tersebut. Kesatuan tersebut diterapkan terhadap kompleks unsur-unsur yuridis seperti peraturan hukum, asas hukum dan pengertian hukum.

Berdasarkan definisi sistem hukum tersebut di atas maka dalam sistem hukum terdapat unsur-unsur sebagai berikut: (1) adanya berbagai komponen, (2) adanya fungsi masing-masing komponen, (3) adanya saling ketergantungan dan saling hubungan antar komponen, (4) adanya keterpaduan antara komponen, (5) semua komponen mengarah kepada tujuan yang telah ditetapkan.

Menurut C.F.G. Sunaryati Hartono, yang dikutip oleh Firman Muntaqo sistem hukum adalah seluruh falsafah hukum, nilai-nilai, asasasas, dan norma hukum, maupun aparatur dan lain-lain sumber daya manusia yang tergabung dalam lembaga dan organisasi hukum

\footnotetext{
${ }^{38}$ Winardi, Pengantar Tentng Teori Sistem Dan Analisis Sistem, Mandar Maju Bandung, hal. 10
}

${ }^{39}$ Ismail Saleh, Majalah Hukum Badan Pembinaan Hukum Nasional,Departemen Kehakiman, No.119, Edisi Khusus, hal 13

${ }^{40}$ Solly Lubis, Ilmu Pengetahuan Perundang-Undangan, Mandar Maju Bandung, 2009, hal. 5.

${ }^{41}$ Sudikno Mertokusumo, Mengenal Hukum Suatu Pengantar, Liberty, Yogyakarta, 1991, hal. 102 
selanjutnya, proses dan prosedur serta interaksi dan pelaksanaan hukum yang secara utuh mewujudkan dan menggambarkan kehadiran tatanan hukum (rechtsorde dan rechtsordening) yang menumbuh kembangkan tatanan hukum kehidupan berbangsa dan bernegara dan bermasyarakat yang berdasarkan nilai-nilai Pancasila dan UUD 1945. ${ }^{42}$ Fungsi dari sitem hukum menurut Friedmann sebagaimana dikutip oleh Muhammad Syaifuddin adalah... to distribute and maintain an alocation of values that society feels to be right. This allocation, invested with a sense of rightness, is what is commonly referred to as justice, yang artinya untuk mendistribusikan dan memelihara nilai-nilai yang dinilai benar oleh masyarakat, yang merujuk pada keadilan. Jadi, output atau tujuan akhir dari sistem hukum adalah terwujudnya keadilan dalam masyarakat. ${ }^{43}$

Kemudian mengenai komponen sistem hukum terdiri dari: Pertama, struktur. Yang dimaksud struktur adalah keseluruhan institusi hukum yang ada beserta aparatnya, yang antara lain terdiri dari kepolisisan dengan para polisinya, kejaksaan dengan para jaksanya, pengadilan dengan para hakimnya. Kedua, substansi. Yang dimaksud substansi adalah keseluruhan aturan hukum, norma hukum dan asas hukum, baik yang tertulis maupun yang tidak tertulis, termasuk putusan pengadilan. Ketiga, kultur hukum. Yang dimaksu kultur hukum adalah opini-opini, kepercayaan-kepercayaan, kebiasaan-kebiasaan, cara berpikir dan cara bertindak, baik dari penegak hukum maupun warga masyarakat tentang hukum dan berbagai fenomena yang berkaitan dengan hukum. ${ }^{44}$

Menurut Achmad Ali, komponen sistem hukum tidak hanya tiga macam, tetapi ada 5 lima macam, yakni struktur, substansi, budaya, profesionalisme dan kepemimpinan. Yang dimaskud profesionalisme adalah kemampuan dan ketrampilan secara person dari sosok-sosok penegak hukum. Yang dimaksud dengan kepemimpinan adalah kemampuan dan ketrampilan secara person dari sosok penegak hukum, utamnaya kalangan petinggi hukum.

Efektif tidaknya penegakkan hukum di dunia ini, termasuk Indonesia, terkait erat dengan efektif tidaknya ketiga komponen hukum tersebut. Apabila ketiga unsur tersebut berjalan tidak efektif, maka supremasi hukum dan keadilan akan sulit terealisasikan, yang mengakibatkan kepercayaan warga terhadap law enforcement menjadi luntur dan masyarakat masuk dalam suasana bad trust society, bahkan masuk dalam kualifikasi worst trust society. ${ }^{45}$

42 Firman Muntaqo, Harmonisasi Hukum Investasi Bidang Perkebunan, Disertasi, Program Doktor Ilmu Hukum Universitas Diponegpro, Semarang, hal. 59.

${ }^{43}$ Muhammad Syaifuddin,Perlindungan Hukum Hak Masyarakat Kurang Dan Tidak Mampu Atas Pelayanan Kesehatan Rumah Sakit Swasta Berbadan Hukum Perseroan Terbatas, Universitas Brawijaya, Disertasi, hal. 24.

44 Achmad Ali, Menguak Teori Hukum dan Teori Peradilan, Kencana Prenada Media Group,Jakarta, 2010, hal. 204.

${ }^{45}$ Achmad Ali, "Keterpurukan Hukum di Indonesia Penyebab dan Solusinya”, (Jakarta: Ghalia Indonesia, 2002), hal. 9. 
Dalam penyelesaian seng waris di Pengadilan Agama dari segi lembaganya, aparatnya dan cara penyelesainnya dengan menggunkan aturan hukum yang bersumber dari hukum Islam sehingga dari segi struktur dan kultur hukum sudah tidak ada masalah. Tetapi dari segi substansi hukumnya masih ada masalah karena hukum acara yang digunakan untuk menyelesaikan sengketa waris tidak menggunakan acara yang bersumber dari hukum Islam. Dengan demikian komponen sistem hukum dalam penyelesaian sengekta waris yang terdiri dari struktur hukum, substansi hukum dan budaya hukum belum ada keselarasan.

\section{Penutup}

Dari uraian tersebut maka dapat diambi kesimpulan sebagai berikut:

Pengadilan Agama dalam menyelesaikan sengketa waris menggunakan hukum acara HIR/RBG, tidak menggunakan hukum acara yang bersumber dari hukum Islam disebabkan:

1) Dalam kebijakan politik, Pemerintah kolonil Belanda telah melkukan diskriminasi terhadap hukum Islam.

2) Dalam kebijakan hukum Pemerintah kolonial Belanda telah melakukan univikasi hukum dan kodivikasi hukum kolonial Belanda di Hindi Belanda

3) Dari segi teori hukum, penyelesaian sengketa waris di Pengadilan Agama dengan menggunakan HIR/RBG telahmembuat tidaka ada keselaras antara komponen hukum yang terdiri dari struktur hukum, substansi hukum dan budaya hukum. 


\section{Daftar Pustaka}

Abdurrahman, Kompilasi Hukum Islam di Indonesia, Jakarta: Akademi Presindo, 1992.

al-Asyqar, Umar Sulaiman. Tarikh al-Fiqh, al Islami, Terjemahan Drs.Dedi Jumaedi dan Ahmad Nurahman, Fiqih Islam Sejarah Pembentukan dan Perkembangannya, Jakarta: Akademika Pressindo, 2001.

Ali, Achmad. Menguak Teori Hukum dan Teori Peradilan, Kencana Prenada Jakarta: Media Group, 2010.

Keterpurukan Hukum di Indonesia Penyebab dan Solusinya, Jakarta: Ghalia Indonesia, 2002.

As-Sadr, Muhammad Baqir. Lesson in Islamic Jurisprudence, England: Oneworld Oxford, 2005.

Asyrof, Ahmad Muchsin. "Syari'at Islam dan Hukum Positif di Indonesia" dalam Jurnal Hukum Program Studi Ilmu Hukum Pascasarjana Universitas Sriwijaya, Volume VI Nomor I Januari 2008.

Amirin, Tatang M. Pokok-Pokok Teori Sistem, Jakarta: Rajawali Pers, 1996.

Fuadi, Munir. Teori Negara Hukum Modern (rechttstaat), Bandung: PT Refika Aditama, 2009.

Januri, Moh. Fauzan. Pengantar Hukum Islam Pranata Sosial, Bandung: Pustaka Setia, 2013.

Jazuni, Legislasi Hukum Islam Di Indonesia, Bandung: Citra Aditya Bakti 2005.

Kansil, C.S.T. Pengantar Ilmu Hukum Indonesia, Jakarta: Rineka Cipta, 2014.

Lubis, Suharwardi K. dan Komis Simanjuntak, Hukum Waris Islam, Jakarta: Sinar Grafika, 2013.

Lubis, Solly. Ilmu Pengetahuan Perundang-Undangan, Bandung: Mandar Maju 2009.

Mahfud MD., Moh. Politik Hukum di Indonesia, Jakarta: Rajawali Pers, 2011

Manan, Abdul. Reformasi Hukum Islam di Indonesia, Jakarta: Raja Grafindo Persada, 2006.

Mertokusumo, Sudikno. Mengenal Hukum Suatu Pengantar, Yogyakarta: Liberty, 1991.

Muntaqo, Firman. Harmonisasi Hukum Investasi Bidang Perkebunan, Disertasi, Program Doktor Ilmu Hukum Universitas Diponegpro, Semarang.

Noer, Deliar. Gerakan Modern Islam di Indonesia, 1900-1942, Jakarta: LP3ES, 1980. 
Puspa, Yan Pramudya. Kamus Hukum Edisi Lengkap Bahasa Belanda, Indonesia, Inggris, Semarang: Aneka Ilmu, 1977.

Rahardjo, Satjipto. Ilmu Hukum, Bandung: Citra Aditya Bakti, 2012.

Rasjidi, Lili dan I.B.Wyasa Putra, Hukum Sebagai Suatu Sistem, Bandung: Mandar Maju, 2003.

Soekanto, Soerjono. dan Mustafa Abdullah, Sosiologi Hukum dalam Masyarakat, Jakarta: Rajawali, 1980. dan Purnadi Purbacaraka,Sendi-Sendi Ilmu Hukum, Citra Bandung: Aditya Bakti, 1993.

Syarifuddin, Amir. Hukum Kewarisan Islam, Jakarta: Kencana, 2008.

Syaifuddin, Muhammad. Perlindungan Hukum Hak Masyarakat Kurang Dan Tidak Mampu Atas Pelayanan Kesehatan Rumah Sakit Swasta Berbadan Hukum Perseroan Terbatas, Universitas Brawijaya, Disertasi

Suminto, Aqib. Politik Islam Hindia Belanda, Jakarta: LP3ES, 1985.

Tanuwidjaja, Henny. Hukum Waris Menurut BW, Bandung: Refika Aditama, 2012.

Wahjono, Padmo. Indonesia Negara Berdasarkan Atas Hukum, Jakarta: Ghalia Indonesia, 1983.

Wignjosoebroto, Soetandyo. Dari Hukum Kolonial Ke Hukum Nasional, Jakarta: Raja Grafindo Persada, 1995.

, Hukum, Paradigma, Metode dan Dinamika Masalahnya, Jakarta: ELSAM, 2002.

Winardi, Pengantar Tentang Teori Sistem Dan Analisis Sistem, Bandung: Mandar Maju, tanpa tahun. 